\title{
The Effect of Profitability and Tangibility on Capital Structures
}

\author{
S. Sulastri ${ }^{1, *}$ Putri ${ }^{2,}$ Heraeni Tanuatmodjo ${ }^{3}$ \\ ${ }^{1}$ Universitas Pendidikan Indonesia \\ ${ }^{2}$ Universitas Pendidikan Indonesia \\ ${ }^{3}$ Universitas Pendidikan Indonesia \\ *Corresponding author. Email: sulastri@upi.edu
}

\begin{abstract}
The aims of this study to determine the overview of the profitability measured by Return On Equity (ROE), tangibility, and the capital structure measured by Debt to Equity Ratio (DER), and to know the profitability and tangibility of the capital structure. The research methods used are descriptive and verificative. The research population is a sub-sector company of Pharmaceuticals registered in the Indonesian Stock Exchange period 2012-2017. Samples were taken with purposive sampling techniques. The analytical techniques used are classical assumption testing and panel regression analysis, and hypothesis testing using the F test and T-test. The results revealed that the development of profitability decreased, the development of tangibility increased, and the development of capital structures that experienced increases and decreases that tend to decline. Based on the F test, the profitability and tangibility are pensive to the capital structure. Based on the T-test, profitability affects the capital structure, and tangibility does not affect the capital structure.
\end{abstract}

Keywords: Profitability, Tangibility, Capital Structure.

\section{INTRODUCTION}

Companies always need capital both in opening new businesses or developing businesses. Meeting the business capital can be done through internal and external funding. Corporate internal funding can take the form of retained earnings and depreciation, while external funds are funds originating from creditors, bondholders, and corporate owner funds [1]. In essence, the problem of funding concerns the company's financial balance. The balance is reflected between assets and liabilities [2]. Assets are economic resources owned by the company expressed in units of money, while liabilities (liabilities) are corporate sacrifices that must be paid to third parties that enter into liabilities are capital (equity) and debt [3]. The greater the funds used, the greater the operational activities it does. Likewise, the smaller the funds used, the lower the operational activities [4]. The capital structure is vital for the company because it involves financial decisions related to optimal business funding.

The company's operational activities can run well if its financial manager is right in making corporate funding decisions. A good funding decision can be seen from the company's capital structure. Capital structure is a combination or the balance between debt and own capital used by the company to plan to get capital. The greater the funds used, the greater the operational activities it does. Likewise, the smaller the funds used, the lower the operational activities [4].

The capital structure is vital for the company because it involves financial decisions related to optimal business funding. An optimal capital structure is a condition where a company can use a combination of debt and equity, which is to balance the company's value and its capital costs [5].

Capital structure can be measured from the ratio of total debt to equity, commonly called the debt to equity ratio (DER). DER can indicate the level of risk of a company. The higher the DER ratio, the higher the risk that will occur in a company because the company's funding from the element of debt is greater than its own capital. DER in the calculation is debt divided by own capital, meaning that if the company's debt is higher than its own capital, it means that the DER ratio is more than 
one or the use of debt is greater in funding the company's activities [6].

Based on capital structure theory and previous research, most of them use two independent variables: profitability and tangibility. This is because profitability and tangibility variables are factors that influence funding decisions. So that in this study, the authors used these two variables as factors that influenced the capital structure.

The theory of capital structure was started in 1958 by Modigliani and Miller. Next, [7] put forward a Pecking Order Theory, which discusses the order of corporate financing. Reference [8] and Rubinstein discussed the theory of the Trade-Off Theory capital structure. The capital structure theory used in this research is the Pecking Order Theory. Pecking Order Theory Theory in capital structure is one of the most influential theories of capital structure [9]

Pecking Order Theory assumes that the company aims to maximize the welfare of shareholders. The company prefers internal financing, namely funding from the company's operating results in retained earnings [10]. This theory was first introduced by [7], while Myers did the naming of the Pecking Order Theory in 1984 [11]. reference [12] uses the premise that there is no specific DER target where there is only a hierarchy of sources of funds that companies prefer. This theory explains why profitable companies generally use small amounts of debt because companies have a low DER target. After all, they require little external financing. Less profitable companies will tend to use greater debt for two reasons, namely, (1) insufficient internal funds, and (2) debt is the preferred external source. Therefore, this pecking order theory creates a hierarchy of funding sources, namely internal (retained earnings) and external (debt and stock).

\section{METHODS}

The research method used in this research is descriptive and verification methods. Descriptive research is research conducted to determine the value of independent variables, either one or more variables, without comparing or connecting with other variables [13].

This study's independent variable is profitability using the Return On Equity indicator and tangibility, while the dependent variable is the capital structure using the Debt to Equity Ratio indicator. The population is all pharmaceuticals sub-sector companies listed on the Indonesia Stock Exchange in the 2012-2017 period.

The study was conducted on the financial statements of 9 sample companies during the 2012-2017 period of six years. So the observation data in this study amounted to 54 data.

\section{RESULT AND DISCUSSION}

\subsection{Profitability}

In this study, profitability is measured by the Return On Equity (ROE) indicator. ROE is a ratio that shows the company's ability to generate profit after tax by using the company's own capital. The following is a statistical table of the profitability of the pharmaceuticals sub-sector companies listed on the IDX for the 2012-2017 period shown by Fig. 1

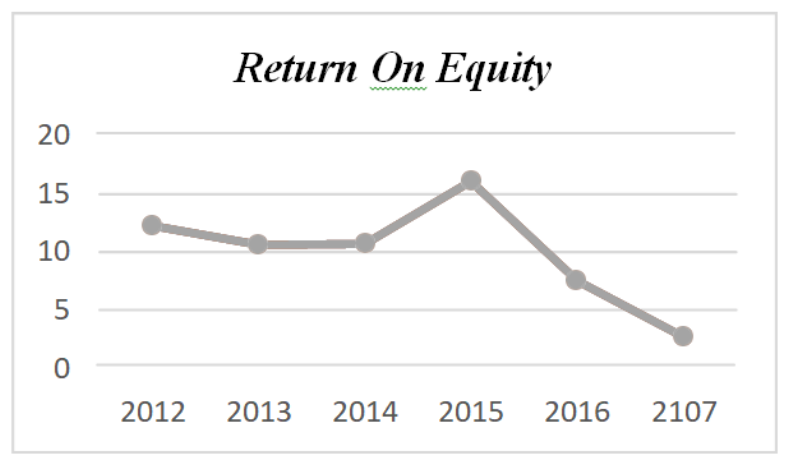

Figure 1. Average Profitability of PharmaceuticalsSubSector Companies listed on the IDX for the period 20122017

Based on Figure 1, it can be seen that the six-year average ROE from $2012-2017$ is 0.0996 or $9.96 \%$. This means that every Rp. 1.- Own capital can generate a profit of Rp. 0.099.- or each use of Rp. 100, - own capital can generate a profit of Rp. 9.96 .

\subsection{Tangibility}

Tangibility shows the level of ability of tangible assets that act as collateral. In this study, based on thedata that has been obtained, the tangibility of the pharmaceuticals sub-sector companies that theyowned from 2011 to 2017 experienced a stable movement. The following is a statistical table of the tangibility of the pharmaceuticals sub-sector companies listed on the IDX for the 2012-2017 period shown by Fig. 2 .

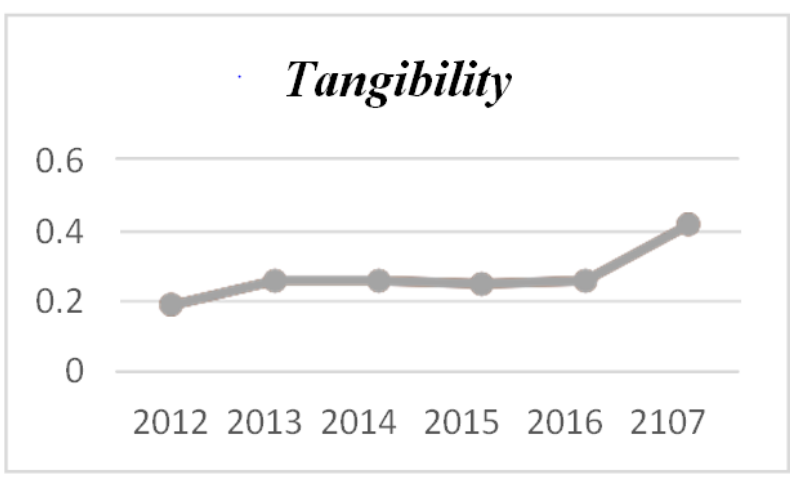

Figure 2. Average Tangibility of Pharmaceuticals SubSector Companies listed on the IDX for the period 2012 2017. 
Based on Figure 2, it can be seen that the average tangibility for the last six years is 0.0194 or $1.94 \%$. This means that every Rp. 1, - the company's debt can be guaranteed by a tangibility of Rp. 0.0194, - or every Rp. 100 - the company's debt will be guaranteed by the tangibility of Rp. 1.94, -.

\subsection{Capital structure}

In the period 2012 to 2017 , the average DER of the pharmaceuticals sub-sector companies listed on the IDX was -1.15 and has fluctuated every year but shows a downward trend, as shown in Fig. 3 below.

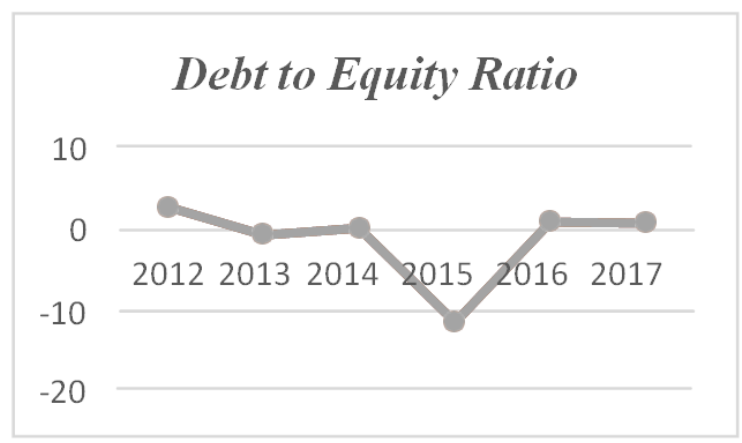

Figure 3. Average Capital Structure of Pharmaceuticals Sub-Sector Companies listed on the IDX for the period 2012-2017.

Based on Figure 3, it can be seen that the average DER of the pharmaceuticals sub-sector listed on the IDX for the 2012-2017 period is -0.012 or $-1.2 \%$. This means that every Rp. 1, - own capital can guarantee Rp. -0.012 of the debt or every Rp. 100, - own capital guarantees a debt of Rp. -1,2, -

\subsection{Hypothesis testing}

\section{Effect of profitability on capital structure}

Based on the results of the significance of the regression coefficient test, the prob (F-statistic) obtained was $0.00(<0.05)$. Then $\mathrm{H} 0$ is rejected, and $\mathrm{Ha}$ is accepted, the profitability variable (ROE) has a t-value of -10.58 , which is then compared to the t-table value of distribution $\mathrm{t}$ with degrees of freedom $=51$ (nk) and a significance level of $5 \%$ or 0.05 , so a t-table value is obtained $(-10.58<0.67)$. It can be concluded that the profitability variable (ROE) affects the capital structure (DER).

The value of the regression coefficient for the profitability variable is $-1,601$. This means that profitability (ROE) has a negative relationship to the capital structure (DER) because if profitability rises by $1 \%$, then the capital structure will decrease by $-1,601$.

These results support the pecking order theory, indicating a negative relationship between profitability and capital structure. This is because the increase in profits will increase the amount of retained earnings, so the number of internal funds that can be used increases and decreases debt use. The results of this study support research conducted by [14-19] where the results of the study show that profitability has a negative effect on capital structure.

\section{Effect of tangibility on capital structure}

Based on the results of the significance of the regression coefficient test, the prob (F-statistic) obtained was 0.93 (> 0.05). Then $\mathrm{HO}$ is accepted, and $\mathrm{Ha}$ is rejected, the tangibility variable has a tcount of 0.08 , which is then compared with the $t$ value of the distribution of $\mathrm{t}$ with degrees of freedom $=51(\mathrm{nk})$ and $\mathrm{a}$ significance level of $5 \%$ or 0.05 , so a t-table value $(0.08$ is obtained $<0.67)$. Then it can be concluded that the tangibility variable influences the capital structure (DER). The value of the regression coefficient for the tangibility variable is 0.51 . This means that tangibility has a positive relationship withcapital structure (DER) because if profitability rises by $1 \%$, the capital structure will increase by 0.51 . Sotangibility is used as one of the factors used by companies to consider capital structure. Because tangibility describes the proportion of the company's fixed assets to total assets. These results support the pecking order theory, which predicts a positive relationship to the tangibility of the capital structure (DER). Companies that have high assets thatcan be used as debt guarantees tend to use relatively large. The results of this study support the research conducted by [20-22] to obtain results that tangibility has a significant positive effect on capital structure. This is based on the theory of the Pecking Order Theory.

\section{CONCLUSION}

Based on the research that has been done, the following conclusions can be drawn: (1) The profitability picture of the Pharmaceuticals sub-sector from 2012 to 2017 as measured by Return on Equity (ROE) tends to decrease with an average ROE of $10 \%$. The highest ROE was achieved in 2015 of $16.07 \%$, with the highest ROE owned by PT Merck Sharp Dohme Pharma which was $54.1 \%$, while the lowest ROE occurred in 2017, which was $2.71 \%$, and the company that had the lowest ROE was PT Indofarma Persero which is $-16.72 \%$. (2) The description of the Pharmaceuticals sub-sector's tangibility during the period of 2012 to 2017 tends to increase with an average tangibility of $1.94 \%$. The highest tangibility achieved in 2014 amounted to $10.26 \%$ owned by PT Pyridam Farma Tbk that is equal to $0.55 \%$, while the lowest tangibility occurred in 2012, which was $0.19 \% \%$, and the company that had the lowest tangibility was PT Pyridam Farma Tbk which was equal to $0.01 \%$. (3) The description of the Pharmaceuticals sub-sector's capital structure during the period of 2012 to 2017 as measured by Debt to Equity Ratio (DER) tends to 
increase with an average DER of $-1.2 \%$. The highest DER was achieved in 2012 at $2.85 \%$, with the highest DER owned by PT Merck Sharp Dohme Pharma which was $22.13 \%$, while the lowest DER occurred in 2015, which was $-11.37 \%$, and the company that had the lowest DER was PT Merck Sharp Dohme Pharma is -107\%. (4) Based on the results of hypothesis testing, profitability and tangibility variables affect the capital structure. (5) Based on the hypothesis testing results, the profitability variable has a negative effect on capital structure, while tangibility has a positive effect on capital structure. So it can be concluded that the direction of capital structure policy used by Pharmaceuticals sub-sector companies uses the pecking order theory.

\section{REFERENCES}

[1] J. Lina, "Analisis faktor-faktor yang mempengaruhi struktur modal perusahaan manufaktur," Accounting. Global. J., no. 12, vol. 2, pp. 81-96, 2020.

[2] D. Hariyanti, "Analisis pengaruh return on assets dan beban pajak daerah air minum kabupaten maluku tengah,” J. Ekonomi. Mododerasi., vol. 4, no. 3, pp. 174-183, 2008.

[3] A.H. Jusup, Dasar-dasar akuntansi jilid. Yogyakarta: Bagian Penerbitan Sekolah Tinggi Ilmu YKPN, 2013.

[4] Erari, "Analisis pengaruh current ratio, debt to equity ratio, dan return on asset terhadap return saham pada perusahaan pertambangan di Bursa Efek Indonesia," J. Manaj. Bisnis Univ. Muhammadiyah Yogyakarta, vol. 5, no. 2, pp. 174-191, 2014.

[5] R.P. Angeliend, "analisis struktur modal dan faktorfaktor yang mempengaruhinya (studi pada sektor manufaktur di BEI)," J. Ekon. dan Bisnis, pp. 1-15, 2011.

[6] E.F. Brigham, and J.F. Houston, Manajemen keuangan, 8 Ed. Jakarta: Erlangga, 2001.

[7] C. Donaldson, Corporate debt capacity. Harvard University, 1961.

[8] R.A. Haugen and J.L. Pappas, "Equilibrium in the Pricing of capital assets, risk-bearing debt instruments, and the question of optimal capital structure,”J. Financ. Quant. Anal., 1971.

[9] N.N. Bundala, "Do Tanzanian companies practice pecking order theory, agency cost theory or trade-off theory? An empirical study in Tanzanian listed companies,” Int. J. Econics Financial Issues, vol. 2, no. 4, 2012.
[10] C. Nuswandari, "Determinan struktur modal dalam prespektif pecking order theory dan agency theory," J. ISSN., vol. 2, pp. 1979- 4878, 2013.

[11] Y. Prabansari, and H. Kusuma, "Faktor-faktor yang mempengaruhi struktur modal pada perusahaan manufaktur Go public yang terdapat di Bursa Efek Jakarta," Sinergi: Kajian Bisnis dan Manajemen., 2015.

[12] S.C. Myers, "Determinants of corporate borrowing," J. finance economies., no. 5, pp. 147-155, 1977.

[13] Sugiyono, Metode penelitian kuantitatif dan kualitatif R\&D. Bandung: Alfabeta, 2012.

[14] S. Titman and R. Wessels, "The Determinants of Capital Structure Choice,” J. Finance, vol. 43, no. 1, pp. 1-19, 1988.

[15] N. Michaelas, F. Chittenden, and P. Poutziouris, "Financial policy and capital structure choice in u.k. smes: empirical evidence from company panel data," Small Bus. Econ., pp. 113-130, 1999.

[16] J. Al-Ajmi, H. Abo Hussain, and N. Al-Saleh, "Decisions on capital structure in a Zakat environment with prohibition of riba: The case of Saudi Arabia," J. Risk Finance., vol. 10, no. 5, pp. 460-476, 2009.

[17] G. Morri and A. Artegiani, "The effects of the global financial crisis on the capital structure of EPRA/NAREIT Europe index companies," J. Europe Real Estate Research., vol. 8, no. 1, 2015.

[18] U.V. Finky, and E. Ernawati, "Faktor-faktor yang memengaruhi struktur modal pada industri property dan real estate yang terdaftar di BEI Periode 20082011”, J. Ilmiah. Universitas Surabaya., vol. 2, no. 10, pp. 1-13, 2013.

[19] J.H. Liem, B.S. Sutejo, and W.R. Murhadi, "Faktorfaktor yang mempengaruhi struktur modal pada industri," J. Ilmiah Mahasiswa Universitas Surabaya., vol. 2, no.1, pp. 1-11, 2013.

[20] G.H. Wardhana, "Pengaruh profitability, asset tangibility dan institutional ownership terhadap struktur modal dan dampaknya pada kebijakan dividen,"J. Bisnis Strategi., vol. 21, no. 1, pp. 95 $111,2017$.

[21]F.M. Abu Mouamer, "The determinants of capital structure of Palestine-listed companies," J. Risk Finance., vol. 12, no. 3, pp. 226-241, 2011.

[22] Ramjee and T. Gwatidzo, "Dynamics in capital structure determinants in South Africa," Meditari Accountancy Research., vol. 20, no. 1, pp. 52-67, 2012. 